ఠ

Open Access Full Text Article

CASE REPORT

\title{
Anti-Factor $V$ inhibitor in patients with autoimmune diseases: case report and literature review
}

This article was published in the following Dove Press journal:

International Medical Case Reports Journal

19 April 201 I

Number of times this article has been viewed

\section{Shinsaku Imashuku' \\ Takeshi Hasegawa ${ }^{2}$ \\ Kagekatsu Kubo² \\ Masaki Nakato ${ }^{2}$ \\ Midori Shima ${ }^{3}$ \\ 'Division of Pediatrics and Hematology, ${ }^{2}$ Division of Internal Medicine, Takasago-Seibu Hospital, Takasago, Hyogo; ${ }^{3}$ Department of Pediatrics, Nara Medical University, Kashihara, Nara, Japan}

Correspondence: Shinsaku Imashuku Division of Pediatrics and Hematology, Takasago-Seibu Hospital, I-I0-4I Nakasuji, Takasago, Japan 676-08I2

Tel +81 794470100

Fax +81 794470180

Email shinim95@mbox.kyoto-inet.or.jp

\begin{abstract}
Acquired anti-Factor $V$ deficiency caused by inhibitor production is a rare coagulation disorder. Although this is a well known entity in the literature, choice of optimal treatment for an individual patient is difficult, given that no standard therapeutic measures are available because of rare incidence and various underlying diseases occurring in the elderly. An 88 year-old man treated for Hashimoto's disease was found to exhibit prolongation of both prothrombin time and activated partial thromboplastin time. Detailed study of coagulation factors revealed a deficiency of Factor V. Our patient's coagulation disorder resolved in two weeks with intravenous administration of prednisolone $20 \mathrm{mg}$ /day. Clinical features of autoimmune disease-related Factor $\mathrm{V}$ deficiency are discussed, along with eight previously reported cases over the past 20 years.

Keywords: anti-Factor V inhibitor, Hashimoto's thyroiditis, autoimmune disease
\end{abstract}

\section{Introduction}

Acquired Factor $\mathrm{V}$ deficiency, which usually arises as a result of inhibitor production, was described a long time ago and is a well recognized condition. ${ }^{1,2}$ However, its incidence is very low compared with that of acquired Factor VIII deficiency. The clinical symptoms of acquired Factor $\mathrm{V}$ deficiency are quite variable because they range from asymptomatic to severe hemorrhagic diathesis. ${ }^{1,2}$ This means that physicians are often puzzled when they see patients who lack a tendency towards hemorrhage yet simultaneously exhibit prolongation of both prothrombin time and activated partial thromboplastin time. Acquired Factor V deficiency generally occurs in the context of topical use of bovine thrombin, malignancies, pregnancy, antibiotic use, and autoimmune disease. However, the association with autoimmune disease appears to be less frequent. In addition, the relevance of anti-Factor $\mathrm{V}$ inhibitor to other autoimmune antibodies remains unclear. ${ }^{2}$ We report here an elderly man with Hashimoto's disease who was incidentally diagnosed with asymptomatic Factor V deficiency. We also summarize the previously reported cases of Factor $\mathrm{V}$ deficiency that are associated with autoimmune diseases.

\section{Case report}

Between 2009 and 2010, our patient, an 88-year-old man, was treated for Hashimoto's disease and frequent premature ventricular contractions using levothyroxine sodium hydrate $75 \mu \mathrm{g} /$ day and mexiletine hydrochloride $150 \mathrm{mg} /$ day. During this period, his cardiac function was stable. The patient had been diagnosed with Hashimoto's thyroiditis in August 2009 due to a high level of thyroid-stimulating hormone $(127 \mu \mathrm{IU} / \mathrm{mL})$, low free T4 $(0.1 \mathrm{ng} / \mathrm{dL})$, and low free T3 $(<0.3 \mathrm{pg} / \mathrm{mL})$ levels. This profile was accompanied 
by high antithyroglobulin antibody $(3840 \mathrm{U} / \mathrm{mL})$ and antithyroid peroxidase antibody (191 U/mL) levels. Tests for other autoimmune disease-related antibodies, such as antinuclear antibody and anti-SSA and anti-SSB antibodies, were negative. At the time when Hashimoto's disease was diagnosed, the patient's coagulation data were normal. In July 2010, the patient had been admitted to hospital with a diagnosis of aspiration pneumonia. In the several weeks prior to his admission, he did not have any other infections or medication use. On admission, he was free from hemorrhagic diathesis, but exhibited microscopic hematuria. However, his coagulation data were abnormal, ie, prothrombin time $13.6 \%$ (reference range $72 \%-116 \%$ ), International Normalized Ratio (INR) 4.21 (0.84-1.14), and activated partial thromboplastin time $102(25.2-40.0) \mathrm{sec}$. His prothrombin time and activated partial thromboplastin time values were not corrected by treatment with fresh frozen plasma. Further detailed analysis of the coagulation factors revealed the following data: Factor II 49\% (62\%-127\%), Factor $\mathrm{V}<1 \%$ (50\%-150\%), Factor VII 100\% (65\%-135\%), Factor VIII $60 \%$ (50\%-150\%), Factor IV 67\% (60\%-140\%), Factor X 67\% (56\%-138\%), Factor XI 45\% (65\%-135\%), Factor XII 51\% (50\%-150\%), Factor XIII 125\% (>70\%), and von Willebrand factor $190 \%(50 \%-150 \%)$. This indicated that Factor V was strongly deficient, in association with slightly reduced Factor II and Factor XI activity. An enzyme-linked immunosorbent assay then revealed the presence of an IgGtype Factor $V$ inhibitor (4.3 Bethesda units $/ \mathrm{mL}$ ). The patient was negative for lupus anticoagulant and anticardiolipin/ antiCL-beta2GP1 antibodies. The other laboratory data were as follows: fibrinogen 415 (normal range 146-380) $\mathrm{mg} / \mathrm{dL}$, fibrin degradation products $11.4(<5) \mu \mathrm{g} / \mathrm{mL}$, antithrombin III $86 \%(80 \%-125 \%)$, thrombin-antithrombin III 3.8 $(<3.2) \mathrm{ng} / \mathrm{mL}$, and alpha2-plasmin inhibitor-plasmin complex $2.2(<0.8) \mu \mathrm{g} / \mathrm{mL}$. The patient responded rapidly to intravenous administration of prednisolone $20 \mathrm{mg} /$ day, and obtained normal prothrombin time and activated partial thromboplastin time values within two weeks.

\section{Discussion}

A literature survey revealed just eight autoimmune diseaserelated cases with acquired Factor $\mathrm{V}$ deficiency over the past 20 years $^{3-10}$ (Table 1). Analysis of these cases along with our own revealed that seven of the nine cases were males. The median age was 74 (range 59-88) years. Six had notable bleeding symptoms but the remaining three (including our case) had no or only mild symptoms. The degree to which Factor V levels had dropped ranged widely from $<1 \%$ to $11 \%$. The IgG-type Factor $\mathrm{V}$ inhibitor levels ranged from 3 to 85 Bethesda units $/ \mathrm{mL}$. In terms of underlying disease, four had Hashimoto's disease, two had rheumatoid arthritis, and there was one case each of Sjogren's syndrome, cold agglutinin disease, and dermatomyositis. However, four cases were also associated with malignancies. Thus, it remains unclear whether acquired Factor V deficiency associated with autoimmune disease is truly a distinct entity. Although the reason for higher association with Hashimoto's thyroiditis remains unknown, this fact may indicate that possible triggers exist related to the thyroiditis that induce inhibition of Factor V. In addition, the reason why Factor V deficiency in our case was noted together with reduced Factor II and Factor XI activity remains unknown. In the past, acquired Factor $\mathrm{V}$ deficiency in association with reduced Factor II and Factor X activity has been mentioned in two cases. These cases had no clearly defined underlying disease and responded well to prednisolone treatment. ${ }^{11}$

The clinical features of acquired Factor $V$ deficiency vary from asymptomatic to severe hemorrhagic tendency, as seen in Table 1. Regarding the reasons for a wide range of symptoms, the most important determinants are said to be the specific characteristics of the antibody, ie, antibody titer, whether or not the antibody has access to platelet Factor V, and the Factor $\mathrm{V}$ epitope recognized by the antibody. ${ }^{12}$ It has been reported that inhibitory anti-FV antibodies frequently bind to a common region within the $\mathrm{C} 2$ domain. ${ }^{13}$ Unfortunately, we could not further characterize the domain to which the inhibitor in our case was exactly directed. It is known that Factor $\mathrm{V}$ is distributed between two pools in humans, ie, $80 \%$ circulates in plasma and $20 \%$ is stored in platelets. Thus, the role of platelet Factor $\mathrm{V}$ is underscored in cases of acquired Factor V deficiency, where platelets become crucial players and may be responsible for variable phenotypic expression of the disease. Platelet Factor V is released on platelet activation after dissociation of multimerin at the bleeding site and acts to prevent hemorrhages. ${ }^{14}$

In terms of treatment and outcome, in three of the five cases where steroids, with or without additional therapy, were given for the coagulation abnormality, the inhibitors disappeared in less than two weeks. In total, five cases recovered without complications, but two had cerebral infarction/hemorrhages and two died. These observations suggest that the early introduction of corticosteroids may be useful for cases of acquired Factor $\mathrm{V}$ deficiency in association with autoimmune disease. The poor response to fresh frozen plasma in these cases was due to its low concentration of Factor V, which could be easily inactivated by circulating 


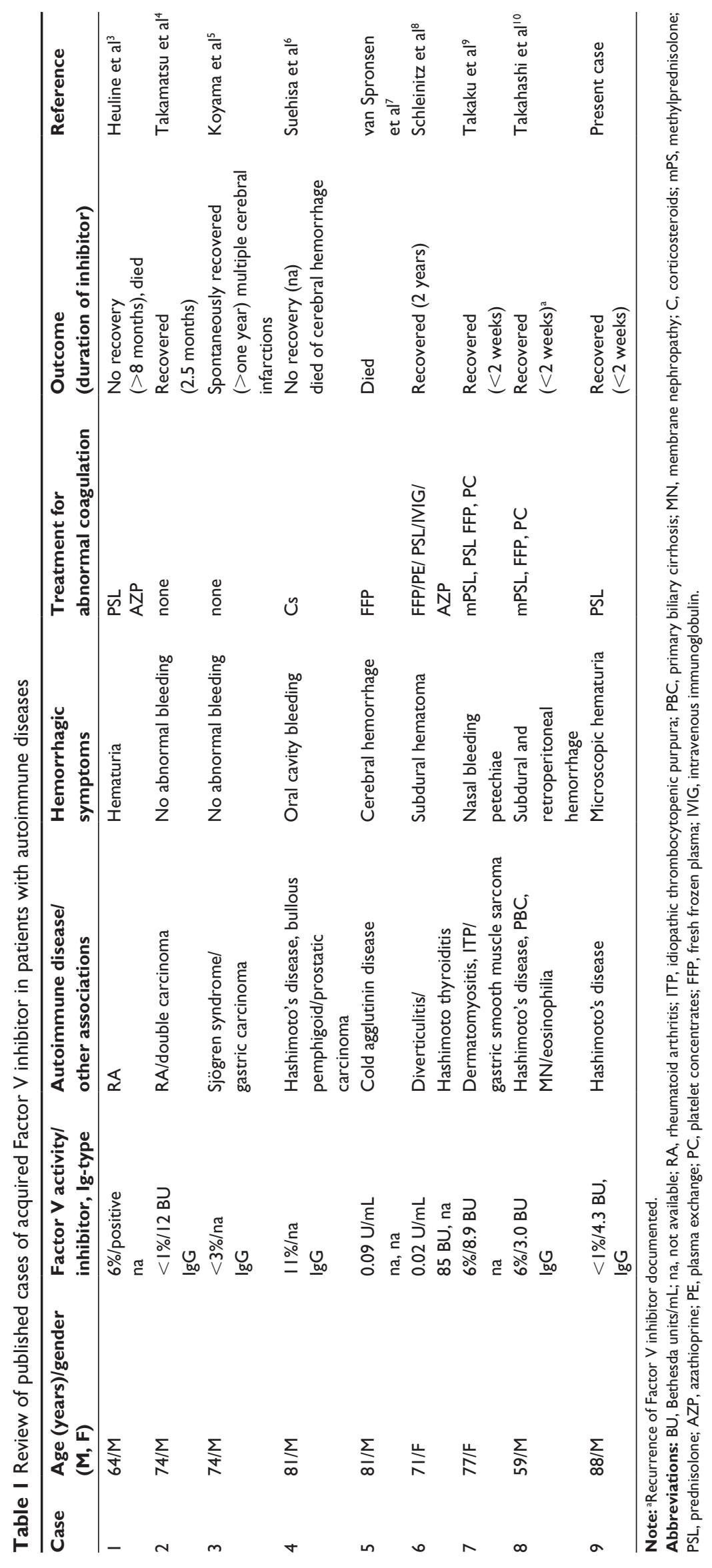


inhibitors. ${ }^{2}$ In cases with severe bleeding, platelet transfusion/ plasma exchange or intravenous immunoglobulin and chemotherapy were used as recommended ${ }^{2}$ (Table 1).

Considering the prompt response to prednisolone in three of the cases, it seems that the inhibitor against Factor $\mathrm{V}$ in these autoimmune cases may have been induced incidentally by unknown trigger(s), unassociated with persistent autoimmune mechanism-related antibody production.

\section{Disclosure}

The authors report no conflicts of interest in this work.

\section{References}

1. Nesheim ME, Nichols WL, Cole TL, et al. Isolation and study of an acquired inhibitor of human coagulation factor V. J Clin Invest. 1986;77: 405-415.

2. Ang AL, Kuperan P, Ng CH, Ng HJ. Acquired factor V inhibitor. A problem based systematic review. Thromb Haemost. 2009;26:852-859.

3. Heuline A, Siame JL, Jude B, Parquet A. Anti-factor V acquired circulating anticoagulant in rheumatoid arthritis. Rev Rhum Mal Osteoartic. 1990;57:442. French.

4. Takamatsu J, Sugiura I, Kagami K, et al. Factor V inhibitor found in a patient with rheumatoid arthritis and double cancer (laryngeal cancer and early stomach cancer). Jpn J Thromb Hemost. 1992;3:271-276. Japanese.
5. Koyama T, Saito T, Kusano T, Hirosawa S. Factor V inhibitor associated with Sjögren's syndrome. Br J Haematol. 1995;89:893-896.

6. Suehisa E, Toku M, Akita N, et al. Study on an antibody against F1F2 fragment of human factor V in a patient with Hashimoto's disease and bullous pemphigoid. Thromb Res. 1995;77:63-68.

7. van Spronsen DJ, Oosting JD, Hoffmann JJML, Breed WPM. Factor V inhibitor with cold agglutinin disease. Ann Hematol. 1998;76:49-50.

8. Schleinitz N, Veit V, Chouquet D, et al. Acquired factor V inhibitor: Etiology, bleeding risk and therapeutic management with regard to three cases. Rev Med Interne. 2001;22:1119-1123. French.

9. Takaku T, Kuriyama Y, Shoji N, et al. Simultaneous development of factor $\mathrm{V}$ inhibitor and autoimmune thrombocytopenia in a patient with dermatomyositis. Rinsho Ketsueki. 2002;43:1050-1054. Japanese.

10. Takahashi H, Fuse I, Abe T, et al. Acquired factor V inhibitor complicated by Hashimoto's thyroiditis, primary biliary cirrhosis and membranous nephropathy. Blood Coagul Fibrinolysis. 2003;14:87-93.

11. Shimizu I, Ichikawa N, Yotsumoto M, et al. High-titer idiopathic acquired factor $\mathrm{V}$ inhibitor patient showing decreased activities of multiple coagulation factors. Rinsho Ketsueki. 2008;49:413-416. Japanese.

12. Knobl P, Lechner K. Acquired factor V inhibitors. Baillieres Clin Haematol. 1998;11:305-318.

13. Ortel TL, Moore KD, Quinn-Allen MA, et al. Inhibitory anti-factor $\mathrm{V}$ antibodies bind to the factor $\mathrm{V} \mathrm{C} 2$ domain and are associated with hemorrhagic manifestations. Blood. 1998;91:4188-4196.

14. Duckers C, Simioni P, Rosing J, et al. Advances in understanding the bleeding diathesis in factor $\mathrm{V}$ deficiency. Br J Haematol. 2009;146:17-26.
International Medical Case Reports Journal

\section{Publish your work in this journal}

The International Medical Case Reports Journal is an international, peer-reviewed open-access journal publishing original case reports from all medical specialties. Previously unpublished medical posters are also accepted relating to any area of clinical or preclinical science. Submissions should not normally exceed 2,000 words or

\section{Dovepress}

4 published pages including figures, diagrams and references. The manuscript management system is completely online and includes a very quick and fair peer-review system, which is all easy to use. Visit $\mathrm{http}: / / \mathrm{www}$.dovepress.com/testimonials.php to read real quotes from published authors. 